\title{
ANALISIS PELAKSANAAN PERATURAN WALIKOTA NO.40 TH. 2014 TENTANG PEDOMAN PROGRAM FASILITASI PEMBERDAYAAN MASYARAKAT DI KECAMATAN MOJOROTO KOTA KEDIRI
}

\author{
*Fauziah Hanum \\ Program Studi Administrasi Publik Universitas Kadiri, Indonesia \\ *Email Korespondensi : hanum@unik-kediri.ac.id
}

\begin{abstract}
Abstrak
Program Pemberdayaan Masyarakat (PRODAMAS) adalah kegiatan Pemerintah Kota Kediri untuk meningkatkan kesejahteraan masyarakat. Sasaran program adalah masyarakat di wilayah Rukun Tetangga di Kota Kediri, yakni penguatan kelembagaan, pelatihan, keterampilan dan kegiatan sosial untuk menambah respon akan kesadaran berpartisipasi dalam perencanaan adalah sebuah kesulitan tersendiri. Pada waktu melakukan pembangunan sarana dan prasarana dasar lingkungan yang seharusnya melibatkan warga masyarakat sering terjadi hal sebaliknya yaitu timbul rasa enggan dari warga karena mereka merasa kegiatan itu hanya memberikan manfaat bagi kelompok tertentu. Hasilnya pelaksanaan pembangunan dasar lingkungan kurang memuaskan disebabkan tidak sesuai dengan keinginan warga. Pengawasan yang di harapkan timbul dengan sendirinya tidak efektif karena pembuatan perencanaan pembangunan serta kegiatan pelaksanaan pembangunan yang seharusnya dilakukan oleh masyarakat sedikitpun tampaknya masih jauh dari harapan karena adanya anggapan bahwa yang bertugas melakukan pengawasan adalah pihak panitia atau pemerintah yang telah dibentuk sehingga cenderung masyarakat tidak melakukan pengawasan. Disisi lain ada sikap masyarakat yang kurang mendukung. Dengan alasan itulah peneliti tertarik untuk menganalisis pelaksanaan peraturan Walikota Kediri No 40 Tahun 2014 di Kecamatan Mojoroto Kota Kediri. Analisis yang digunakan dalam penelitian ni adalah analisis deskriptif. Hasil penelitian dan fokus penelitian adalah tahapan perencanaan telah dilaksanakan sesuai dengan pedoman pelaksanaan tahapan pelaksana.
\end{abstract}

Kata Kunci: Prodamas; Pelaksanaan; Pemberdayaan

\begin{abstract}
Comunnity empowerment program (PRODAMAS) is an activity of the Kediri city government to improve community welfare. The target of the program is the community in the neighborhood in Kediri City, namely strengthening institutions, training, skills and social activities to increase the response to the awareness of participating in planning is a difficulty in itself. When building basic environmental facilities and infrastructure that should involve community members, the opposite often occurs, namely reluctance from residents because they feel that these activities only benefit certain groups. The result is that the implementation of basic environmental development is not satisfactory because it is not in accordance with the wishes of the resident. The supervision that is expected to arise by itself is ineffective because the making of development planning and the implementation of development activities that should be carried out by the community is still far
\end{abstract}


from being expected because of the assumption that the task of supervising is a committee or government that has been formed so that the community tends not to carry out supervision. On the other hand, there is an attitude of society that is less supportive. For this reason, researchers are interested in analyzing the implementation of Kediri Mayor Regulation No. 40/2014 in Mojoroto District, Kediri City. The analysis used in this research is descriptive analysis. The results of the research and the focus of the research are that the planning stages have been carried out in accordance with the guidelines for implementing the implementation stages.

Keywords: Prodamas; Implementation; Empowerment

\section{PENDAHULUAN}

Sebagaimana tertuang pada Undang-Undang No. 23 tahun 2014, pemerintah pusat memberi kewenangan otonomi pada daerah berupa desentraliasi baik kabupaten maupun kota yang berdasarkan pada azas desentralisasi dalam mewujudkan otonomi yang luas, nyata dan bertanggung jawab, adanya otonomi daerah pada kabupaten dan kota membuat keleluasaan untuk pengembangan potensi ekonomi di wilayahnya berdasarkan model yang sesuai dengan keinginan dan harapan masyarakat.

Disamping itu pemerintah daerah baik kabupaten maupun kota memiliki kewenangan pada pemahaman desentralisasi melalui Grand Theory definisi yang lain desentralisasi menurut Romainells 3 skema kewenangan ini meliputi: perencanaan, pelaksanaan, pengawasan, pengendalian dan evaluasi pada semua aspek pemerintahan.

Dalam tindakan untuk mengevaluasi kegagalan pemerintah Kota Kediri mengambil tindakan beralih ke pendekatan model prespektif dana partisipatif (Bottom up Planning). Untuk menindaklanjuti harapan dan program dalam menjalankan otonomi daerah yang berkaitan dengan pendekatan model pembangunan partisipatif dan prespektif, pemerintah Kota Kediri mengambil langkah mengeluarkan satu kebijakan peraturan pemerintah daerah No. 40 tahun 2014 tentang pedoman program fasilitas pemberdayaan masyarakat. Program ini merujuk pada fasilitasi pemberdayaan masyarakat/prodamas agar hidup lebih sejahtera. Menurut BAPPEDA Kota Kediri adalah daerah perencanaan pembangunannya melibatkan berbagai elemen masyarakat dan stakeholders.

Program pemberdayaan masyarakat (PRODAMAS) merupakan salah satu upaya Pemerintah Kota Kediri dalam peningkatan kesejahteraan masyarakat (Kurniawati, 2017). Pendekatan yang digunakan dalam program ini yakni pendekatan pemberdayaan masyarakat yang mana perencanaan, pelaksanaan, pengawasan dan evaluasi adalah 
tahapannya. Cakupan program ini adalah seluruh aspek kehidupan dan penghidupan masyarakat baik fisik maupun non fisik, melalui lembaga kemasyarakatan yang terdapat di kelurahan dengan tugas pemberian bantuan langsung pada masyarakat.bantuan pada program ini diberikan untuk pembinaan 3 aspek kehidupan masyarakat atau dengan nama lain program Tri Bina yaitu Bina Sosial Ekonomi, Bina Sosial, dan Bina Fisik Lingkungan.

Dalam pelaksanaan pembangunan sarana dan prasarana seharusnya ada keterlibatan seluruh warga. Namun yang terjadi justru sebaliknya, perencanaan dan pelaksanaan pun tampaknya masih jauh dari harapan, karena adanya anggapan pengawas yang bertugas adalah pihak yang memerintah atau panitia pelaksana yang telah dibentuk sehingga ada kecenderungan masyarakat untuk tidak melakukan pengawasan (Djanggih $\&$ Salle, 2017).

Berdasarkan pengamatan peneliti dilapangan terdapat dua sikap masyarakat dalam menanggapi program pemberdayaan masyarakat dari pemerintah daerah. Sisi yang pertama adalah masyarakat yang aktif dan setuju, dan sisi yang lain adalah masyarakat pasif, kurang mendukung dan acuh tak acuh.

Berdasarkan penjelasan dari latar belakang diatas maka rumusan persoalan masalah dalam penelitian ini sebagai berikut :

1. Bagaimanakah pelaksanaan Peraturan Pemerintah Kota Kediri No 40 Tahun 2014 di Kecamatan Mojoroto Kota Kediri.

2. Hambatan apa yang ditemukan dalam pelaksanaan Peraturan Pemerintah Kota Kediri No 40 Tahun 2014 di Kecamatan Mojoroto Kota Kediri

\section{TINJAUAN PUSTAKA}

Sebelum peneliti memahami makna, definisi dari kebijakan (Handoyo, 2012) adalah serangkaian tindakan yang mampunyai tujuan tertentu yang diikuti dan 
dilaksanakan oleh seorang pelaku atau sekelompok pelaku guna memecahkan suatu masyalah tertentu.

Sedangkan menurut (Mulyadi, 2016) kebijakan adalah merupakan suatu program yang diproyeksikan dari tujuan-tujuan nilai-nilai dan praktik serta tindakan.

Dari pendapat dua ahli tersebut diatas dapat ditarik satu garis besar kebijakan adalah serangkaian tindakan untuk mencapai suatu tujuan tertentu. Keterkaitan pada penelitian ini yang dimaksud dengan kebijakanadalah kebijakan pemerintah yang diartikan sebagaisebuah serangkaian konsep yang menjadi garis besar dasar perencanaan dalam pelaksanaan suatu aktivitas kerja dan cara cara bertindak. Hal ini sesuai dengan pendapat Thomas R. DYE yang diterjemahkan Leo Agustinos bahwa kebijakan publik adalah apa yang dipilih oleh pemerintah untuk dikerjakan atau tidak dikerjakan (Anggara, 2014).

Berdasarkan pendapat Roem Topar Masang dkk kebijakan publik adalah suatu sistem pembuatan, pelaksanaan dan pengendalian keputusan-keputusan yang menyangkut kepentingan masyarakat luas (Tahir, 2014) .

Dari pendapat tersebut di atas dapat ditarik garis besar bahwa kebijakan publik adalah serangkaian tindakan yang dikembangkan oleh pemerintah untuk mencapai tujuan yang didalam nya menyangkut kepentingan publik.

\section{Pengertian Implementasi Kebijakan Publik}

Pada umumnya tugas implementasi adalah mengaitkan realisasi tujuan kebijakan public dengan hasil kegiatan pemerintah. Tugas Implementasi meliputi kreasi tentang system pengiriman kebijakan, didesain dengan cara khusus dan diupayakan dengan harapan mencapai tujuan khusus tersebut.

Menurut Erwan Agus dkk, implementasi kebijakan publik adalah kegiatan mendistribusikan keluaran kebijakan (to deliver policy output) yang dilakukan implementer kepada kelompok sasaran (target group) sebagai upaya mewujudkan tujuan kebijakan, tujuan kebijakan diharapkan akan muncul mana kala policy output dapat diterima, dana dimanfaaatkan dengan baik oleh kelompok sasaran, sehingga dalam jangka panjang hasil kebijakan akan mampu diwujudkan (Purwanto, 2012). 
Menurut Ekowati menyatakan implementasi kebijakan publik adalah sebuah fungsi dari implementasi program dan tergantung pada hasilnya sebagai suatu konsekuensi studi tentang proses.implementasi kebijakan adalah melibatkan penelitian dan analisa konkrit program aksi yang telah di desain sedemikian rupa sebagai suatu cara mencapai tujuan kebijakan yang luas. Keberhasilan dan kegagalan suatu implementasi dapat diliahat dari hasil implementasi program yang ditetapkan berdasar ukuran bersifat persial dari keberhasilan atau kegagalan implementasi kebijakan secara menyeluruh (Abidin, 2012).

Berdasarkan hal tersebut dapat ditarik suatu kesimpulan bahwasannya implementasi kebijakan pada dasarnya merupakan suatu interaksi serta penyusunan tujuan sarana tindakan untuk mencapai tujuan dengan mengembangkan sebab akibat yang melahirkan adanya implementasi kebijakan dalam suatu program yang menjadi kegiatan suatu birokrasi.Selain itu implementasi kebijakan bisa dilihat sebagai sebuah bidang kajian.pandangan ini tidak dapat dilepaskan dari upaya para ahli untuk memahami masalah implementasi itu sendiri. Elemen penting dalam sebuah implementasi adalah:

\section{Subject matter (ontology)}

2. Cara memahami obyek yang dipelajari (epistemology)

3. Rekomendasi tindakan yang di perlukan (aksiologi)

Perlu dipahami bahwa implementasi suatu kebijakan atau program dilakukan yang didalamnya terdapat berbagai faktor antara lain kondisi geografi, sosial, ekonomi dan politik yang memiliki kontribusi penting dalam implementasi kebijakan (Ramdhani \& Ramdhani, 2017).

\section{Pengertian pemberdayaan masyarakat}

Pemberdayaan masyarakat menurut Sumodiningrat merupakan upaya untuk memandirikan masyarakat lewat perwujudan potensi kemampuan yang mereka miliki 
untuk menentukan pilihan kegiatan yang paling sesuai bagi kemajuan diri mereka masingmasing (Prasetyo, 2016).

Lebih lanjut Kartasasmita menyatakan pemberdayaan adalah upaya meningkatkan harkat dan martabat lapisan masyarakat yang dalam kondisi tidak mampu untuk melepaskan diri dari perangkap kemiskinan dan keterbelakangan atau dengan kata lain memberdayakan masyarakat adalah memampukan dan memandirikan masyarakat (Noor, 2011) .

Upaya untuk memandirikan masyarakat melalui perwujudan potensi untuk menentukan pilihan kegiatan yang paling sesuai juga ditegaskan oleh Siswanto menyatakan secara empiris banyak studi yang menunjukkan bahwa masyarakat lebih mampu mengidentifikasi, menilai dan memformulasikan permasalahannya baik fisik, sosial, kultur maupun ekonomi dan kesehatan lingkungan, membangun visi dan aspirasi dan kemudian memprioritaskan intervensi, merencana, mengelola, memonitor dan bahkan memilih teknologi yang tepat.

Menurut Meriam upaya untuk memampukan dan memandirikan masyarakat pemberdayaan mengandung dua pengertian yakni:

1. Upaya meningkatkan kemampuan masyarakat melalui pelaksanaan berbagai kebijakan dan program-program pembangunan agar koordinasi kehidupan masyarakat mencapai tingkat kemampuan yang diharapkan.

2. Memberikan kekuasaan, mengalihkan kekuasaaan atau mendelegasikan otoritas kepada masyarakat agar msayarakat memiliki kemandirian dalam pengambilan keputusan dalam rangka membangun diri dan lingkungannya secara mandiri.

Dari definisi di atas maka dapat disimpulkan bahwa pemberdayaan adalah upaya dari masyarakat untuk mendapatkan kehidupan yang lebih baik dari berbagai hal.

\section{Program Pemberdayaan Masyarakat (PRODAMAS)}

Selama ini program pembangunan yang dijalankan oleh pemerintah kurang memiliki dampak yang efektif terhadap kebutuhan masyarakat secara keseluruhan. Hal ini terjadi di sebabkan karena pemerintah selama ini kurang melibatkan elemen masayrakat dan stakeholder (pemangku kepentingan di lingkungan birokrasi maupun 
masyarakat) dalam perencanaan, pelaksanaan, serta evaluasi pembangunan.strategi pembangunan yang dijalankan pemerintah belum mampu mengubah apapun kepada masyarakat. Dampaknya adalah program pembangunan yang dilaksanakan pemerintah tidak bisa menjawab permasalahan kebutuhan masyarakat pemerintah Kota Kediri.

Berdasarkan Peraturan Wali Kota Kediri No 40 Th 2015 pemberdayaan masyarakat adalah suatu strategi yang digunakan dalam pembangunan masyarakat sebagai upaya untuk mewujudkan kemampuan dan kemandirian dalam kehidupan bermasyarakat, berbangsa, dan bernegara.

Menurut perda No 40 Th 2015 secara konsepsional pemberdayaan masyarakat memiliki 2 pengertian dasar sebagai berikut.

a. Memberi kekuasaan, mengalihkan kekuasaan atau mendelegasikan otoritas kepada masyarakat agar masyarakat mempunyai kemandirian dalam pengambilan keputusan untuk membangun dirinya sendiri dan

b. Lingkungannya secara mandiri.

c. Meningkatkan kemampuan masyarakat melalui pelaksanaan berbagai kebijaksanaan dan program pembangunan agar kondisi kehidupan masyarakat mencapai tingkat kemampuan yang diharapkan.

Dalam rangka menumbuh kembangkan, menggerakkan, partisipasi masyarakat dalam pembangunan maka diperlukan fasilitas pemberdayaan masyarakat dari pemerintah Kota Kediri yang dijalankan sesuai prinsip pengelolaan Prodamas yakni sebagai berikut :

1. Transparan

2. Partisipatif

3. Akuntabel

4. Berkelanjutan

Variabel yang mempengaruhi pelaksanaan program pemberdayaan masyarakat adalah menurut pendapat Van Meter dan Van Horn yaitu komunikasi, sikap pelaksana, dukungan masyarakat

Komunikasi sangat berpengaruh terhadap keberhasilan program pemberdayaan masyarakat. Dengan adanya komunikasi maka penyampaian pesan dari pemerintah tentang pelaksanaan prodamas akan jelas dan dapat langsung dimengerti oleh kelompok 
sasaran (RT), selain itu usulan dari masyarakat lewat komunikasi selanjutnya ditanggapi oleh pemerintah. Komunikasi menurut Onong Uchjana Effendy adalah proses penyampaian suatu pesan dari sekelompok orang kepada orang lain untuk memberitahukan atau mengubah sikap, pendapat atau perilaku baik langsung secara lisan maupun tidak langsung melalui media (Romli, 2017).

Sedangkan menurut Ani Muhammad komunikasi dibedakan menjadi tiga :

1. Komunikasi kebawah, yaitu arus pesan yang menghindari para atasan atau para pimpinan kepada bawahannya, pesan biasanya berhubungan dengan pengarahan, tujuahn, disiplin, perintah, kebijaksanaan umum.

2. Komunikasi keatas, adalah pesan yang mengalir dari bawah kepada atasan atau dari tingkat yang lebih rendah ke tempat yang lebih tinggi. Tujuannya untuk memberikan balikan memberi saran dan menunjukan pertanyaan, informasi dari bawah dapat berupa laporan yang dicapai, kemajuan dan rencana masa yang akan dating. Menyampaikan masalah yang dihadapi menyampaikan saran ide.

3. Komunikasi horizontal, adalah pertukaran pesan diantara orang-orang yang sama tingkatan otoritasnya, pesan biasanya berhubungan dengan tugas, koordinasi, pemecahan masalah dan sedang memberi informasi. Dalam kaitannya dengan pelaksanaan program pemberdayaan masyarakat.

Sikap pelaksana (pendapat Van Meter dan Van Horn, Grindle, Sebater dan Maz Marion)

"Dalam pelaksanaan program sikap pelaksana juga ikut menentukan kebersihasilan program tersebut, karena dengan adanya pelaksana maka pesan dari pemerintah maupun usulan dari masyarakat dapat berjalan dengan lancar, sehingga dapat mendukung kelancaran pelaksanaan program.”

Dalam Kamus Besar Fisikologi Sikap (Attitude/pendirian) dimaksud sebagai sesuatu predisposisi atau kecenderungan yang relate stabil dan berlangsung terus menerus untuk tingkah laku atau untuk mereka dengan cara tertentu terhadap pribadi lain, objek, lembaga atau tertentu dilihat dari satutitik pandang yang sedikit beda, sikap merupakan kecenderungan untuk mereaksi terhadap orang, institusi atau kejadian baik positif maupun negatif. 
Mas Manian dan Sabatier mengatakan sikap pelaksana sebagai komitmen para pelaksana sebagai komitmen para pelaksana terhadap tujuan yang telah ditetapkan sebagaimana dinyatakan oleh (Akib, 2012) bagaimanapun baiknya suatu undang-undang atau keputusan kebijaksanaan dasar lainnya menstruktur proses keputusan formal, upaya pencapaian tujuan resmi yang dimaksud untuk mengubah perilaku kelompok sasaran tidak akan membawa hasil yang diharapkan terkecuali kalau pejabat dalam badan-badan pelaksana memilih kesepakatan (komitmen) yang tinggi terhadap upaya pelaksanaan PRODAMAS.

Dalam pelaksanaan prodamas para pelaksana antara lain (Perda No. 40 Tahun 2004).

a. Tim koordinasi prodamas Kota Kediri

b. Tenaga pendamping

c. Tim koordinasi prodamas kecamatan

d. Tim koordinasi prodamas kelurahan

e. Tim swa kelola prodamas

f. Tim perencana

g. Tim pengawas

h. Tim pelaksana

i. RT

Dukungan masyarakat / kelompok / publik menurut Mazmanian dan Sabatier diartikan sebagai masukan-masukan atau input yang berasal dari masyarakat dalam upaya untuk mendukung kelancaran suatu pelaksanaan program. Dukungan kelompok sasaran/masyarakat akan dilihat dari peran aktif dari tim koordinasi PRODAMAS, tenaga pendamping, tim perencana, tim pelaksana, tim pengawas dalam. Semua tahapan kegiatan selain dukungan kelompok sasaran juga akan dilihat dari kerutinan masyarakat dalam menghadiri setiap kegiatan.

Dalam penelitian ini, peneliti hanya ingin melihat dampak dari adanya program pemberdayaan masyarakat (PRODAMAS) menurut Dunn dalam Samodra Wibawa, dkk dampak kebijakan adalah perubahan kondisi fisik maupun sosial sebagai akibat dari 
output kebijakan. Dampak kebijakan bisa berupa dampak positif maupun negatif atau dampak yang diharapkan maupun yang tak diharapkan.

Restie A Pel membagi dampak kebijakan menjadi 4 kategori yaitu :

a. Direct impact

b. Political impact

c. Economic impact

d. Sosial impact

Dalam kaitannya dengan dampak sosial Riga Adiwoso membagi kedalam 3 jenis dampak yaitu :

a. Dampak sosial ekonomi yang lebih menekankan pada aspek-aspek dalam tingkat individu, kelompok komonitas, maupun daerah dimana kegiatan dilaksanakan.

b. Dampak fisik sosial yaitu dampak yang lebih menekankan kepada dampak sosiologi, termasuk dampak terhadap nilai, sikap, kepercayaan, serta persepsi baik pada tingkat individu maupun kelompok.

c. Dampak sosial budaya, yaitu penekanannya pada individu, kelompok atau penduduk daerah dengan menggunakan bergai disiplin ekonomi termasuk sosiologi, antropologi, psikologi, maupun ilmu-ilmu sosial lainnya.

Suatu kebijakan akan selalu membawa dampak positif maupun negative atau dampak yang diharapkan maupun tidak diharapkan. Dalam penelitian ini hanya memfokuskan pada dampak sosial ekonomi dengan adanya pelaksanaan program pemberdayaan masyarakat/PRODAMAS.

\section{METODE PENELITIAN}

Sesuai dengan jenis masalah yang diteliti maka jenis penelitian yang peneliti pakai adalah jenis penelitian deskriptif kualitatif dan dengan pendekatan policy research, ini berarti sesuatu kegiatan yang berupa suatu penelitian yang dilakukan terhadap variable mandiri tanpa harus membuat perbandingan variable lain. Tetapi juga berusaha menjawab masalah penelitian (Gunawan, 2013). Selain hal tersebut penelitian ini berangkat dari terjadinya suatu masalah dan merupakan suatu proses penelitian/analisis yang dilakukan pada masalah sosial yang mendasar sehingga temuannya dapat diberi rekomendasi pada 
pembuatan keputusan untuk bertindak secara praktis dalam menyelesaikan masalah (Siyoto \& Sodik, 2015). Dalam metode penelitian ini ada 7 teknik dalam pengumpulan data yaitu : Teknik pengumpulan data terdiri dari wawancara, kuesioner, observasi dan dokumentasi. Teknik wawancara, observasi, kuesioner dan dokumentasi dapat digunakan pada penelitian kuantitatif, kualitatif dan pengembangan. Dokumentasi biasa digunakan pada penelitian kualitatif. Pada penelitian kualitatif digunakan teknik triangulasi untuk menginterpretasikan beberapa teknik pengumpulan data (Rahardjo, 2011).

\section{HASIL DAN PEMBAHASAN}

Berdasarkan keseluruhan analisa berkaitan dengan pedoman pelaksanaan dan pelaksanaan analisis program perwali no 40 tahun 2014 pada setiap tahap dapat peneliti menjabarkanSebagaimana hasil penelitian, yang peneliti sajikan di atas yaitu pada tabel Nomor 1, Nomor 2, Nomor 3, dan Nomor 4, maka untuk selanjutnya peneliti akan memaparkan analisa dari masing-masing tahapan.

1. Tahapan penyusunan data dasar

a. Dalam penyusunan data dasar di kecamatan Mojoroto dapat peneliti evaluasi melalui pedoman pelaksanaan dalam pedoman pelaksanaan dalam penyusunan data dasar kelurahan. Melakukan pemilihan lokasi dalam hal ini kelurahan di wilayah kecamatan mojoroto sudah melakukan kegiatan pemilihan lokasi yaitu RT/RW di wilayah kelurahan. Hal ini sudah sesuai dengan pedoman pelaksanaan.

b. Dalam pelaksanaannya seluruh kelurahan di wilayah kecamatan mojoroto dalam pelaksanaannya tiap-tiap kelurahan membentuk tim pembina kelurahan tapi ada sedikit perubahan peran POKJA di ganti fasilitator dengan alasan kegiatan ini adalah kegiatan kelompok, pembentukan dan penetapan tim pembina kelurahan, hal ini sudah sesuai dengan pedoman pelaksanaan.

c. Dalam melakukan evaluasi kerjanya dengan identifikasi masalah, potensi dan kebutuhan masyarakat dilakukan dengan musyawarah dan menggunakan caracara sesuai dengan pedoman pelaksanaan. 
Dengan demikian, dapat di simpulkan kegiatan penyusunan data dasar di kecamatan mojoroto dilihat dari pedoman pelaksanaan dan evaluasi sudah di jalankan sesuai dengan pedoman pelaksanaan.

\section{Tahapan perencanaan}

Berdasarkan pemaparan hasil penelitian pada tabel no 2 di atas, maka peneliti dapat menganalisa membahas berkaitan pedoman pelaksanaan, pelaksana dan evaluasi kecamatan mojoroto dalam tahapan perencanaan program sudah melaksanakan sesuai dengan pedoman pelaksanaan. Disitu berkaitan dengan identifikasi masyarakat dalam penentuan data dasar. Masing-masing RT di kelurahan wilayah Kecamatan Mojoroto, melakukan pengorganisasian masalah dan menentukan peringkat masalah yang paling urgent untuk segera ditindaklanjuti rata-rata permasalahan yang muncul di RT dan kendalanya masyarakat yang kurang modal modal usaha. Penetapan pembentukan organisasi dan penetapan perangkat masalah sudah sesuai pedoman. Dalam kegiatan perencanaan ini menentukan prioritas pemecahan masalah yang tepat dengan melihat potensi yang ada. Sedangkan rencana yang akan dilakukan adalah melakukan penelitian sesuai dengan potensi dengan tujuan menambah pengetahuan dan ketrampilan. Hal ini pelaksanaan sudah sesuai dengan pedoman di samping hal tersebut di RT wilayah Kecamatan Mojoroto pada perencanaan ada pembagian peran. Masyarakat mitra berperan menyampaikan ide gagasan untuk RT sedangkan stakeholder berperan menerima usulan serta menindaklanjuti ini sudah sesuai dengan pedoman pelaksanaan atau belum.

\section{Tahapan pelaksanaan}

Ada pembagian peran yaitu masyarakat mitra berperan sebagai penggagas ide, fasilitator sebagai penampung dan mendampingi dalam pembuatan RTL. Dan menindaklanjuti inin kurang optimal. Evaluasi kegiatan sudah sesuai dengan pedoman pelaksanaan masyarakat, mitra, tim pembina kelurahan dan tim pemerintah daerah terlibat dalam kebijakan evaluasi program.

Program fasilitasi pemberdayaan masyarakat bertujuan meningkatkan kualitas hidup menuju pada kesejahteraan, kesetaraan dan keadilan.Melalui bidang pembangunan, dalam upaya penanganan kemiskinan dengan fokus peningkatan kondisi status, 
kedudukan, dan partisipasi perempuan dengan melibatkan laki-laki, ini dilaksanakan melalui tiga tahapan tersebut adalah :

a. Tahapan perencanaan

b. Tahapan pelaksanaan

c. Tahapan evaluasi

Dalam penelitian ini yang menjadi fokus penelitiannya adalah :

a. Tahapan perencanaan diukur dengan indikator komunikasi, sikap pelaksanaan dan dukungan kelompok.

b. Tahapan pelaksanaan diukur dengan indikator komunikasi, sikap pelaksana dan dukungan kelompok.

c. Tahapan evaluasi diukur dengan indikator komunikasi, sikap pelaksanaan dan dukungan kelompok.

Dilihat dari tahapan perencanaan. Sebelum desa membuat perencanaan terlebih dahulu dialah dengan kegiatan penyusunan data dasar dan melakukan komunikasi dengan warga dibeberapa RT sesuai dengan program yang akan dipakai sebagai pedoman desa untuk membuat perencanaan. Dari tahapan perencanaan tersebut maka peneliti dapat mengambil kesimpulan bahwa di Kecamatan Mojoroto dalam pelaksanaan program pemberdayaan dilihat dari tahapan perencanaan dengan indikator komunikasi, sikap pelaksanaan dan dukungan kelompok menunjukan.

1. Komunikasi sudah berjalan baik

2. Dukungan kelompok baik

3. Kurang memahami cara melakukan identifikasi

Sedagkan hasil penelitian dilihat dari tahapan perencanaan yang dilihat dari indikator komunikasi, sikap pelaksana dan dukungan kelompok sebagai berikut :

Dalam pelaksanaan program pemberdayaan dilihat dari tahapan perencanaan dengan indikator komunikasi, sikap pelaksanaan dan dukungan kelompok menunjukan.

1. Komunikasi sudah berjalan baik

2. Dukungan kelompok baik

3. Sikap pelaksana masih kurang efektif dikarenakan petugas pelaksana kurang memahami cara melakukan identifikasi. 
Dari penggalian informasi dari masyarakat dapat dikatakan pada tujuan pelaksana program pemberdayaan masyarakat Kecamatan Mojoroto sudah baik dan pelaksana sesuai aturan ini terlihat dari komunikasi dalam pelaksana baik, sikap melaksanakan dalam pelaksanaan baik dan dukungan kelompo pada pelaksanaan baik.

Dalam tahapan evaluasi ini oleh penelitian untuk dengan indikator komunikasi.Indikator sikap pelaksana dan tanggapan kelompok siding hasil penelitiannya.

Dari mitra dapat diketahui bahwa dalam pelaksanaan Peraturan Walikota No. 40 Tahun 2014 tentang fasilitas pemberdayaan masyarakat mulai penuh dasar-dasar, kegiatan perencanaan, kegiatan telah sesuai dan kegaitan evaluasi sudah dilakukan sesuai dengan ketentuan walaupun ada juga yang tidak sepenuhnya.

\section{KESIMPULAN DAN SARAN}

\section{Kesimpulan}

Hasil penelitian yang berjudul evaluasi pelaksanaan fasilitas pemberdayaan di Kecamatan Mojoroto Kota Kediri dapat kami simpulkan pelaksanaan program fasilitas pemberdayaan masyarakat dari setiap tahapan dalam pelaksanaan pembangunan prasarana lingkungan mulai dari penyusunan data dasar pembuatan perencanaan program pelaksana serta hanya pengawasan.

1. Dalam pembuatan data dasar yang dilakukan di Kelurahan sudah sesuai dengan ketentuan ada sedikit perubahan berkaitan dengan peran pokja diganti dengan fasilitator dengan alasan program pemberdayaan merupakan program yang bersifat.

\section{Saran}

1. Pemerintah hendaknya berusaha untuk melibatkan seluruh masyarakat dalam pelaksanaan program-program kerja yang telah diciptakan dalam hal ini Program Pemberdayaan Masyarakat, tanpa memandang perbedaan kondisi ekonomi sosial masyarakat.

2. Untuk lebih meningkatkan bentuk partisipasi masyarakat dalam setiap tahapan dalam pelaksanaan pembangunan prasarana lingkungan melalui Program pemberdayaan 
Masyarakat, pemerintah setempat hendaknya memberikan pelatihan, penyuluhan atau peningkatan kemampuan masyarakat, sehingga masyarakat merasa benar-benar terlibat dalam program ini.

3. Perlunya peningkatan intensitas sosialisasi Program Pemberdayaan (PRODAMAS) oleh pemerintah, agar program ini berada pada tingkat kemitraan (partnership), dimana pada tingkat ini partisipasi masyarakat memiliki kekuatan untuk bernegosiasi dengan pemegang kekuasaan dalam melakukan perencanaan, pelaksanaan, pengawasan dan evaluasi.

4. Untuk meningkatkan partisipasi masyarakat dan swasta dalam pembangunan lingkungan melalui program Pemberdayaan Masyarakat (PRODAMAS), dapat dilakukan lewat peningkatan pembinaan melalui penyuluhan, dan pemerintah perlu berinisiatif untuk meningkatkan kualitas seluruh stakeholder dalam setiap tahap pembangunan, termasuk pemerintah sendiri, karena dengan kualitas yang setara diantara para stakeholder akan menghindari konflik karena kepentingan individu maupun golongan.

5. Sedangkan rekomendasi atau saran untuk peneliti selanjutnya adalah perlu dikaji mendalam tentang faktor-faktor yang menjadi pendorong maupun penghambat dari partisipasi masyarakat pada kegiatan pembangunan prasarana lingkungan melalui Program Pemberdayaan Masyarakat (PRODAMAS).

\section{REFERENSI}

Abidin, S. Z. 2012. Kebijakan Publik. Jakarta : Salemba Humanika.

Akib, H. 2012. Implementasi kebijakan: Apa, mengapa dan bagaimana. Jurnal Ilmiah Ilmu Administrasi Publik, 1(1), 1-11.

Anggara, S. 2014. Kebijakan Publik. CV Pustaka Setia.

Djanggih, H., \& Salle, S. 2017. Aspek Hukum Pengadaan Tanah bagi Pelaksanaan Pembangunan untuk Kepentingan Umum. Pandecta: Jurnal Penelitian Ilmu Hukum (Research Law Journal), 12(2), 165-172.

Gunawan, I. 2013. Metode penelitian kualitatif. Jakarta: Bumi Aksara, 143.

Handoyo, E. 2012. Kebijakan Publik. Semarang: Widya Karya. 
Kurniawati, N. 2017. Partisipasi Perempuan Pada Program Pemberdayaan Masyarakat (PRODAMAS) Di Kelurahan Banjar Melati Kecamatan Mojoroto Kota Kediri Jawa Timur. Universitas Airlangga.

Mulyadi, D. 2016. Studi Kebijakan Publik dan Pelayanan Publik: Konsep dan Aplikasi Proses Kebijakan Publik Berbasis Analisis Bukti Untuk Pelayanan Publik.

Noor, M. 2011. Pemberdayaan masyarakat. CIVIS, 1(2/Juli).

Prasetyo, R. A. 2016. Peranan BUMDES dalam Pembangunan dan Pemberdayaan Masyarakat di Desa Pejambon Kecamatan Sumberrejo Kabupaten Bojonegoro. Jurnal Dialektika, 11(1), 86-100.

Purwanto, E. A. 2012. Implementasi Kebijakan Publik Konsep dan Aplikasinya di Indonesia (Issue 1). 2012.

Rahardjo, M. 2011. Metode pengumpulan data penelitian kualitatif.

Ramdhani, A., \& Ramdhani, M. A. 2017. Konsep umum pelaksanaan kebijakan publik. Jurnal Publik, 11(1), 1-12.

Romli, K. 2017. Komunikasi massa. Gramedia Widiasarana.

Siyoto, S., \& Sodik, M. A. 2015. Dasar metodologi penelitian. Literasi Media Publishing.

Tahir, A. 2014. Kebijakan publik dan transparansi penyelenggaraan pemerintahan daerah. Penerbit Alfabeta. 